\title{
An Arbitrage Model for Calculating Firm Beta at Different Leverage Levels
}

\author{
Alka Bramhandkar \\ School of Business, 414 Park Center, Ithaca College \\ Ithaca, NY 14850, USA \\ E-mail: abramhandkar@ithaca.edu \\ Joseph Cheng \\ School of Business, 315 Park Center, Ithaca College \\ Ithaca, NY 14850, USA \\ E-mail: cheng@ithaca.edu \\ Julie Fitzpatrick (Corresponding author) \\ Department of Business Administration \\ E336D Thompson Hall, SUNY Fredonia, Fredonia, NY 14063, USA
}

Tel: 1-716-673-3404 E-mail: Julie.Fitzpatrick@fredonia.edu

Received: August 29, 2012

doi:10.5430/afr.v1n2p207
Accepted: October 15, 2012

Online Published: November 6, 2012

\begin{abstract}
Traditionally, the Hamada Equation is used to estimate a firm's levered beta. However, a major drawback of the Hamada Equation is its assumption that the cost of debt is equal to the risk free rate at all levels of debt. In this paper, we develop an alternative model that could be applied by practitioners to estimate levered betas. The primary advantage of our approach is that it does not require Hamada's assumption that the cost of debt is equal to the risk free rate. Our model is based on the concept that the target or proposed debt level for the firm being evaluated can be replicated via a stock portfolio. In an efficient market where arbitrage can occur, the beta for the firm at the target debt level may be derived from the beta of the replicated stock portfolio.
\end{abstract}

Keywords: Capital structure, Hamada equation, Weighted average cost of capital, Financial leverage, Beta

\section{Introduction}

Capital structure and financing decisions are some of the most important issues in corporate finance. Before making a decision regarding a change in its capital structure, a firm first needs to estimate the effect of the proposed change on its Weighted Average Cost of Capital (WACC). For large firms, the cost of debt is fairly easy to determine since corporate yields can be observed in the market. However, the firm's cost of equity must be estimated.

According to a recent survey, over $70 \%$ of firms "always or almost always" use the Capital Asset Pricing Model (CAPM) to estimate the cost of equity capital (Graham and Harvey, 2001). To apply the CAPM, a firm needs estimates of beta at the proposed capital structure, the risk-free rate and the market risk premium. Traditionally, the Hamada equation is used to estimate the levered beta at various levels of debt (Hamada, 1972). However, the Hamada approach assumes that the cost of debt is equal to the risk-free rate at all levels of debt. This is an unrealistic assumption since a firm's cost of debt increases as additional debt is issued. In this paper, we develop an alternative methodology to estimate beta at any proposed capital structure. The key advantage of our approach is that no assumption regarding the cost of debt is required.

\section{Literature Review}

Numerous ideas have been advanced and empirically examined to explain firms' capital structure decisions. These can be broadly classified into five groups. 


\subsection{Tax Effects}

Previous research has shown that shareholder wealth increases with borrowing (up to a point) because the interest on debt is tax deductible, making debt a cheaper source of financing (Modigliani and Miller, 1963).

\subsection{Trade-off Theory}

According to the trade-off theory, firms borrow up to the point where the marginal benefit from an additional dollar of debt is just equal to the marginal cost, where the marginal benefit is the present value of the interest tax shield and the marginal cost is higher expected bankruptcy cost. Since the tax advantage associated with debt is offset at higher levels of debt by higher expected direct and indirect bankruptcy costs, managers will tend to borrow less (DeAngelo and Masulis, 1980; Leland, 1994).

\subsection{Pecking Order Theory}

Other research has argued that firms follow a "pecking order" when making financing decisions (Myers, 1984). According to this theory, any firm's first choice is internal financing. When internal financing is exhausted, a firm issues debt. Finally, since external equity leads to ownership dilution and carries higher costs, a firm issues new equity only as a last resort. Some empirical research has shown that firms converge to the industry mean while following the idea of a pecking order (Ghosh and Cai, 1999).

\subsection{Signaling Hypotheses}

Several recent models have applied the idea that financing decisions convey managers' private information to the capital markets. To the extent that a debt issuance signals managers' confidence in sufficient future cash flows to service the debt, the issuance of debt is interpreted as a positive signal. On the other hand, a stock issue carries a negative signal because managers only choose to issue external equity when they believe that the current stock price is too high (Myers and Majluf, 1984). Some researchers have found support for the signaling hypothesis; they find positive stock price reactions to firm announcements of bank debt agreements, suggesting that loan approvals are based on access to favorable private information (Fama, 1985; Lucas and McDonald, 1990).

\subsection{Industry Mean Target}

Other research has hypothesized that companies attempt to achieve the average industry leverage ratio over time (Bowen, Daley, and Huber, 1982). This conclusion is supported by some empirical data over five- and ten-year time periods (Javiland and Harris, 1984). Although unusual conditions may prevent companies from adjusting toward the industry mean, convergence to the mean is more common for companies with debt levels above the industry average (Claggett, 1991). Finally, prior research investigates the stock price response for two groups - firms moving away from the industry benchmark and firms moving closer to the industry benchmark - and found significantly more negative returns for the first group (Hull, 1999).

\section{Development of the Model}

The standard approach in corporate finance is to utilize the Hamada Equation to estimate a firm's levered beta. Given the firm's unlevered beta $B_{U}$ (i.e., the firm's beta at zero debt), the firm's beta for any debt level $\left(B_{L}\right)$ is estimated via the formula $\mathrm{B}_{\mathrm{L}}=\mathrm{B}_{\mathrm{U}}[1+(1-\mathrm{t}) \mathrm{D} / \mathrm{E}]$, where $\mathrm{t}=$ tax rate, $\mathrm{D}=$ Total Liabilities, and $\mathrm{E}=$ Shareholders' Equity.

However, the derivation of the Hamada equation is based on the assumption that the cost of debt is equal to the risk-free rate. Since this equality assumption holds for all debt levels, it violates the fundamental financial theory that a firm's cost of debt increases with additional debt due to higher risk of bankruptcy. In light of this drawback, we develop an alternative way of estimating levered betas without requiring this restrictive assumption.

We apply concepts from the Arbitrage Pricing Theory (APT) to the issue of capital structure. This might be considered a breakthrough in the capital structure literature because no assumption about the cost of debt is needed. The only assumption required is that arbitrage is permitted in the equity market and the actions of arbitrageurs keep expected returns of stocks in alignment with their corresponding risk as measured by beta. If we assume that there exist several homogenous firms in the same industry (i.e., several firms with the same operational risk) with different levels of debt, then the difference in beta values for these firms is a function only of their relative debt levels. An arbitrageur can combine stocks of these firms with appropriate weights to create a portfolio with a particular (or desired) replicated debt ratio, where the weight is the percentage invested in the respective stocks.

In an efficient market, this portfolio should have an expected return equal to the expected return of a comparative stock (not part of the portfolio) having the same debt ratio and beta as the portfolio. Otherwise, arbitrageurs could 
long the portfolio and short the comparative stock with the same beta, or vice versa. Thus, the concept here is similar to the arbitrage process in APT.

This arbitrage assumption applies to highly efficient markets where arbitrages can take place. For an arbitrage to be operational, one need only identify two other firms with similar operations as the comparative firm but with different degrees of financial leverage. The arbitrageur can create a portfolio with the high leverage firm and the low leverage firm to replicate a leverage ratio equal to that of a comparative firm. The beta and required return of this portfolio can then be measured against that of the comparative firm to determine whether the portfolio is under- or over-valued relative to the comparative firm.

In general, the risk and return of a portfolio consisting of a high leverage firm $(\mathrm{H})$ and a low leverage firm $(\mathrm{L})$ should equal the risk and return of the comparative firm (C) with a debt ratio equal to the weighted average of the debt ratios of the high and low leverage firms. Based on classical portfolio theory, the beta of the portfolio is the weighted average of the betas of the individual assets in the portfolio. Thus, the expected return of the portfolio is equal to the weighted average of the expected returns of the individual stocks. Otherwise, arbitrage will occur until the expected returns of these stocks/firms are in alignment.

To illustrate this with a simple numerical example, if an investor invests $\$ 50$ in Stock $\mathrm{L}$ which has zero debt and $\$ 50$ in Stock $\mathrm{H}$ which has $40 \%$ debt, then this portfolio would yield risk and return equivalent to that of a firm with $20 \%$ debt (average of $0 \%$ and $40 \%$ ). If Stock $\mathrm{C}$ has $20 \%$ debt, then investing $\$ 50$ in Stock L and $\$ 50$ in Stock H should yield the same risk and return as investing $\$ 100$ in Stock $\mathrm{C}$, since the beta of the portfolio is the weighted average of the betas of individual stocks. Otherwise, an arbitrageur could create a portfolio consisting of Stock L and Stock $\mathrm{H}$ that replicates the debt level of Stock C and arbitrage this portfolio against Stock C. If this portfolio has a lower (higher) expected return than Stock C, then arbitragers can long (short) Stock C and short (long) the portfolio. Such arbitrage activities would bring the expected returns of these three firms in alignment with their respective betas.

This concept is similar to APT and it is the basis for the development of our Arbitrage Model that enables managers to derive the estimated market beta of the firm corresponding to a target level of debt. The derived formula is called the "Arbitrage Formula." Like the Hamada Equation, the Arbitrage Formula yields an estimate of a firm's beta for any level of debt. The main advantage is that the Arbitrage Formula does not require the assumption of a risk-free rate for bond yields at any level of debt.

The beta calculation for a target level of debt can be illustrated via the following example. Suppose that the firm being evaluated has a debt ratio (=Total Debt / Total Assets) of 0.1 and a beta value of 0.8. It is considering issuing additional debt which would raise its debt ratio to 0.2 . To estimate the beta at the target debt ratio of 0.2 , we need to identify a comparative firm that is similar in operations which will be referred to as the reference firm. Ideally, the reference firm should be comparable to the current firm in terms of operating risk - the volatility of operating earnings or Earnings Before Interest and Tax (EBIT) should be similar. This is likely to be the case if the two firms are competitors selling similar products or services. Then we can attribute the majority of the difference in risk to the difference in financial leverage rather than differences in operating risk. If we assume that the reference firm has a debt ratio of 0.4 and a beta of 1.2, then one reference point based on these values can be constructed.

Based on the beta of the reference firm and that of the firm being evaluated, we can estimate the beta for the firm being evaluated at the target debt ratio. This condition may be framed as three points on the beta and debt space as shown in Table 1.

Insert Table 1 here

The firm's managers would like to estimate the firm's beta at the target debt level. Although the beta for the target point is unknown, it can be interpolated from the other two known points. Based on the current point and reference point, we can form a line that maps out the beta values for the entire range of debt ratios.

\subsection{Derivation of the Arbitrage Formula}

Assume that an individual invests an equal amount in Firm L (Low Leverage) with zero debt and Firm H (High Leverage) with $40 \%$ debt. Let the weights represent the proportion of the total portfolio invested in each stock.

If we assume that the individual owns only Firm $\mathrm{L}$ and Firm $\mathrm{H}$, and that the weights for $\mathrm{L}$ and $\mathrm{H}$ are each 0.5 , then the effective debt ratio for the individual's portfolio is the average of the individual firms' debt ratios, or $20 \%$. Thus, the portfolio's replicated debt ratio may be expressed as the weighted average of the debt ratios for the two firms. In other words, the weighted average concept for estimating portfolio beta and expected return applies to debt ratios as well. As an illustration, imagine a holding company that has no assets other than cash to be invested in the stocks of 
Firm L and Firm H. When one invests in the stock (equity) of the firm, it is actually buying the firm's assets as well as assuming its debt (because Equity = Assets - Liabilities). If the holding company invests half of its cash in Firm L and half in Firm $\mathrm{H}$, then the implicit debt ratio of the holding company would be the average of the debt ratio of $\mathrm{L}$ and $\mathrm{H}$. Essentially, the risk of the holding company reflects the risk of the firms that it holds. The more equity it holds in a particular firm, the more the holding company's risk would be reflected by the risk of that firm. Thus, the replicating portfolio can be viewed as such holding company or a proxy of the underlying firms. Based on this proxy relationship, the leverage of the holding company is a weighted average of the leverage of the two firms that it holds.

We begin the derivation with two firms: Firm C (Current) and Firm R (Reference).

Let:

$\mathrm{W}_{\mathrm{C}}=$ weight of Firm $\mathrm{C}$ (C represents Current status, which is the firm being evaluated at its current level of debt)

$\mathrm{W}_{\mathrm{R}}$ = weight of Firm $\mathrm{R}$ ( $\mathrm{R}$ represents Reference, a firm that is comparable to Firm $\mathrm{C}$ in operations but has a different level of debt)

$\mathrm{B}_{\mathrm{C}}=$ current beta for Firm C (Status Quo)

$\mathrm{B}_{\mathrm{R}}=$ beta for reference Firm $\mathrm{R}$

$D_{C}=$ debt to assets ratio for status quo (current debt ratio for the firm being evaluated)

$D_{R}=$ debt to assets ratio for reference firm $R$

$\mathrm{B}_{\mathrm{p}}=$ beta of portfolio consisting of the two companies or two stocks

$D_{p}=$ equivalent debt level for the portfolio or the replicated debt level

We can write the debt level for the portfolio as a weighted average of the debt levels of the individual firms:

$$
\mathrm{D}_{\mathrm{p}}=\mathrm{W}_{\mathrm{c}} \mathrm{D}_{\mathrm{c}}+\left(1-\mathrm{W}_{\mathrm{c}}\right) \mathrm{D}_{\mathrm{R}}
$$

Solving for $\mathrm{W}_{\mathrm{c}}$,

$$
\mathrm{W}_{\mathrm{c}}=\left(\mathrm{D}_{\mathrm{R}}-\mathrm{D}_{\mathrm{p}}\right) /\left(\mathrm{D}_{\mathrm{R}}-\mathrm{D}_{\mathrm{c}}\right)
$$

From classic portfolio theory, the portfolio beta equals the weighted average of individual betas:

$$
\mathrm{B}_{\mathrm{p}}=\mathrm{W}_{\mathrm{c}} \mathrm{B}_{\mathrm{c}}+\left(1-\mathrm{W}_{\mathrm{c}}\right) \mathrm{B}_{\mathrm{R}}
$$

Substituting (2) into (3), we express $\mathrm{B}_{\mathrm{p}}$ as:

$$
B_{p}=\left(D_{R}-D_{p}\right) /\left(D_{R}-D_{c}\right) * B_{c}+\left(1-\left(D_{R}-D_{p}\right) /\left(D_{R}-D_{c}\right)\right) * B_{R}
$$

Similar to the Hamada Equation, equation (4) is the final equation for calculating beta at any target level of debt. Based on (4), the target debt ratio of the firm being evaluated can be replicated by a portfolio with appropriate weights for the stock of the evaluated firm and the reference firm. This portfolio replication concept enables us to calculate the beta or required return of the firm with any degree of leverage. The replicating portfolio concept is a tool that enables us to estimate levered betas in practice. The only information necessary is the correlation with the market, which is captured by beta. Thus, we do not need a market portfolio.

We now consider the firm in its current status. Since the current debt ratio is 0.1 and assuming its current beta value is 0.8 , we substitute 0.1 for $\mathrm{D}_{\mathrm{C}}$ and 0.8 for $\mathrm{B}_{\mathrm{C}}$. Next, we identify an operationally similar firm with higher debt (note that lower debt would work also) which will serve as a reference (Firm R). Assuming that Firm R has a debt ratio of 0.4 and a beta of 1.2 , we then substitute 0.4 for $D_{R}$ and 1.2 for $B_{R}$.

Thus, there are three points: The first point is the status quo point corresponding to Firm $\mathrm{C}$ at the current debt ratio. The second point is the Target point corresponding to Firm $\mathrm{C}$ at the target debt ratio. Finally, the reference point corresponds to Firm R. The point being evaluated is the target point: Firm $\mathrm{C}$ at the new target debt level. The stock corresponding to the firm at the target level of debt can be replicated with a portfolio consisting of stock of Firm C (at the current level debt level) and stock of Firm R (with higher level of debt). Note that if $D_{R}=D_{C}$, then the second point needed for interpolation does not exist. In this situation, it is necessary to find a reference firm with a different level of debt.

We complete the example by calculating beta for Firm C at $20 \%$ debt. First, we obtain the appropriate weights for the two stocks in the portfolio in order to replicate the target level of debt for the firm being evaluated. Equation 2 can be used to solve for the weights: 


$$
\mathrm{W}_{\mathrm{C}}=\left(\mathrm{D}_{\mathrm{R}}-\mathrm{D}_{\mathrm{p}}\right) /\left(\mathrm{D}_{\mathrm{R}}-\mathrm{D}_{\mathrm{C}}\right)=(0.4-0.2) /(0.4-0.1)=2 / 3
$$

Based on the above calculations, investing $2 / 3$ of the portfolio value in Stock $C$ with a debt ratio of 0.1 and $1 / 3$ in Stock $\mathrm{R}$ with a debt ratio of 0.4 creates a portfolio with a replicated debt ratio of 0.2 .

Substituting these weights in Equation 3, we derive the beta of evaluating firm at the target level of debt:

$$
\begin{aligned}
\mathrm{B}_{\mathrm{p}} & =\mathrm{W}_{\mathrm{C}} \mathrm{B}_{\mathrm{C}}+\left(1-\mathrm{W}_{\mathrm{C}}\right) \mathrm{B}_{\mathrm{R}} \\
& =2 / 3(.8)+1 / 3(1.2) \\
& =0.93
\end{aligned}
$$

Thus, the estimated beta of the firm at the target debt ratio of 0.2 is 0.93 .

The two step process above can be combined into a single formula that enables us to calculate beta directly as follows via Equation 4:

$$
\begin{gathered}
\mathrm{B}_{\mathrm{p}}=\left(\mathrm{D}_{\mathrm{R}}-\mathrm{D}_{\mathrm{p}}\right) /\left(\mathrm{D}_{\mathrm{R}}-\mathrm{D}_{\mathrm{C}}\right)^{*} \mathrm{~B}_{\mathrm{C}}+\left(1-\left(\mathrm{D}_{\mathrm{R}}-\mathrm{D}_{\mathrm{p}}\right) /\left(\mathrm{D}_{\mathrm{R}}-\mathrm{D}_{\mathrm{C}}\right)\right)^{*} \mathrm{~B}_{\mathrm{R}} \\
=0.93
\end{gathered}
$$

This approach also applies if the firm is considering a debt level higher than that of Firm R. To illustrate, assume that the debt ratio is 0.4 for the Reference firm but the proposed new debt ratio is 0.6. We can use Equation 2 to find the weight:

$$
\mathrm{W}_{\mathrm{C}}=\left(\mathrm{D}_{\mathrm{R}}-\mathrm{D}_{\mathrm{p}}\right) /\left(\mathrm{D}_{\mathrm{R}}-\mathrm{D}_{\mathrm{C}}\right)=(0.4-0.6) /(0.4-0.1)=-2 / 3=-0.67
$$

Since the sum of the weights equals one, the weight for the Reference firm is 1.67.

Thus, to replicate a debt ratio of 0.6 , we need to short $\$ 0.67$ of Stock $\mathrm{C}$ for every $\$ 1.67$ of Stock R that we long. Any dollar investment amount in this relative proportion will yield a debt ratio of 0.6 .

Substituting these weights in Equation 3, we derive the beta of our firm at the proposed level of debt:

$$
\begin{aligned}
\mathrm{B}_{\mathrm{p}} & =\mathrm{W}_{\mathrm{C}} \mathrm{B}_{\mathrm{C}}+\left(1-\mathrm{W}_{\mathrm{C}}\right) \mathrm{B}_{\mathrm{R}} \\
& =(-0.67)(0.8)+(1.67)(1.2) \\
& =1.47
\end{aligned}
$$

Thus, the estimated beta of the firm at a target debt ratio of 0.6 is 1.47 .

Unlike the Hamada Equation, the Arbitrage Formula can be used to calculate beta for any level of debt without assuming that a firm's cost of debt remains at the risk-free rate at all levels of debt. In addition, the Hamada Equation assumes that $B_{u}$ is known, which might not be realistic. In fact, the value of $B_{u}$ cannot be clearly observed in the real world and in practice must be estimated by "backing it out" via the Hamada Equation. An estimate of $\mathrm{B}_{\mathrm{u}}$ is not necessary in the application of the Arbitrage Model.

\section{Application of the Model}

The Home Depot, Inc. (NYSE: HD) is a home improvement retailer that sells building materials, home improvement products, and lawn and garden products in its stores throughout the United States. Table 2 provides the balance sheet and market value data for Home Depot at 31 October 2010.

\section{Insert Table 2 here}

Its current leverage ratio (= Book Value of Total Liabilities / Total Firm Value) is $30.87 \%$ and its estimated beta is 0.81 . We use a beta estimate published by Yahoo! Finance, although one could also estimate a firm's market beta using regression. Suppose that Home Depot is considering issuing $\$ 1.5$ billion of debt to finance an expansion. Before making a decision regarding the amount of debt issuance, its managers must first estimate the effect on the firm's WACC. To estimate the new cost of equity, the managers need to estimate the new levered beta.

To apply the Arbitrage Model, Home Depot's managers need to identify a firm with similar operations but a different level of leverage. Lowe's Companies, Inc. (NYSE: LOW) is a direct competitor of Home Depot with very similar operations but higher leverage. Table 2 also provides the relevant data for Lowe's at 29 October 2010. As shown in Table 2, Lowe's leverage ratio is $34.41 \%$ and its estimated beta is 1.01 .

We estimate Home Depot's beta at the higher debt level by replicating the target debt level via construction of a portfolio consisting of both Home Depot and Lowe's.

Insert Table 3 here 
If Home Depot issues $\$ 1.5$ billion in debt, then its new leverage ratio is $32.25 \%$. Using Equation 4, Home Depot's beta would increase from 0.81 to 0.89 .

To proceed with a decision regarding this capital structure change, Home Depot's managers would use this beta to estimate the cost of equity at the proposed capital structure by applying the Capital Asset Pricing Model. Assuming that it could estimate its cost of debt by using observable yields, the firm could then estimate its' WACC at the proposed capital structure.

We conclude the application with a comparison of the betas obtained using the Arbitrage Model to those estimated via the Hamada Equation. The Hamada Equation requires an estimate of Home Depot's unlevered beta, Bu. Using Home Depot's current levered beta of 0.81 , current leverage $(\mathrm{D} / \mathrm{V})$, and assuming a tax rate of $35 \%$, we estimate $\mathrm{B}_{\mathrm{u}}=$ 0.63. As shown in Figure 1, the Hamada Equation's estimated betas increase with leverage at an increasing rate, while there is a positive linear relation between leverage and estimated betas obtained via the Arbitrage Model.

\section{Insert Figure 1 here}

\section{Conclusion}

We develop and apply a new model which could be used by practitioners to estimate a firm's levered beta at any proposed capital structure. The approach can be summarized by the following three steps:

1) Identify a firm with similar operations but different financial leverage.

2) Consider the original firm at the current debt ratio as Stock $C$ and the firm that is similar in operations but with different leverage as Stock R.

3) Simulate the beta of the original firm for the target level of debt by replicating the corresponding level of debt through construction of a portfolio consisting of Stock C and Stock R.

As previously noted, the Arbitrage Model works even if the target debt ratio being evaluated is greater than that of Stock R. If the target debt ratio is higher than Stock R's debt ratio, then the weight for Stock C would be negative, meaning that Stock $\mathrm{C}$ would be shorted such that the weight given to Stock $\mathrm{R}$ is greater than one. The model developed and applied in this paper contributes to the field of corporate finance by providing financial managers and practitioners with a practical way to estimate the effects of proposed capital structure changes on cost of capital and thus enables them to better achieve an optimal capital structure.

\section{References}

Bowen, R.M., Daley, L.A., \& Huber, Jr., C.C. (1982). Evidence on the existence and determinants of inter-industry differences in leverage. Financial Management, 11. 10-20. http://dx.doi.org/10.2307/3665227

Brigham, E. \& Houston, J. (2001). Fundamentals of Financial Management. Fort Worth, Texas: Harcourt College Publishers.

Claggett, Jr., E.T. (1991). Capital structure: Convergent and pecking order evidence. Review of Financial Economics, $1,35-48$.

DeAngelo, H. \& Masulis, R.W. (1980). Optimal capital structure under corporate and personal taxation. Journal of Financial Economics, 8, 3-30. http://dx.doi.org/10.1016/0304-405X(80)90019-7

Fama, E. (1985). What's different about banks? Journal of Monetary Economics, 15, 29-39. http://dx.doi.org/10.1016/0304-3932(85)90051-0

Ghosh, A. \& Francis, C. (1999). Capital structure: New evidence of optimality and pecking order theory. American Business Review, 17, 32-38.

Graham, J. \& Harvey, C. (2001). The theory and practice of corporate finance: Evidence from the field. Journal of Financial Economics, 60, 187-243. http://dx.doi.org/10.1016/S0304-405X(01)00044-7

Hamada, R.S. (1972). The effect of the firm's capital structure on the systematic risk of common stocks. Journal of Finance, 27, 435-452. http://dx.doi.org/10.1111/j.1540-6261.1972.tb00971.x

Hull, R.M. (1999). Leverage ratios, industry norms and stock price reaction: An empirical investigation of stock-for-debt transactions. Financial Management, 28, 32-45. http://dx.doi.org/10.2307/3666193

Javiland, A. \& Harris, R.S. (1984). Corporate behavior in adjusting to capital structure and dividend targets: An econometric study. Journal of Finance, 39, 127-145. http://dx.doi.org/10.1111/j.1540-6261.1984.tb03864.x 
Leland, H. (1994). Corporate debt value, bond covenants, and optimal capital structure. Journal of Finance, 49, 1213-1252. http://dx.doi.org/10.1111/j.1540-6261.1994.tb02452.x

Lucas, D. \& McDonald, R. (1990). Equity issues and stock price dynamics. Journal of Finance, 45, 1019-1044. http://dx.doi.org/10.1111/j.1540-6261.1990.tb02425.x

Merton, R.C. (1974). On the pricing of corporate debt: The risk structure of interest rates. Journal of Finance, 29, 449-470.

Modigliani, F. \& Miller, M. (1958). The cost of capital, corporation finance and the theory of investment. American Economic Review, 48, 261-297.

Modigliani, F. \& Miller, M. (1963). Corporate income taxes and the cost of capital. American Economic Review, 53, 433-443.

Myers, S. (1984). The capital structure puzzle. Journal of Finance, 39, 575-592. http://dx.doi.org/10.2307/2327916

Myers, S. \& Majluf, N. (1984). Corporate financing and investment decisions when firms have information that investors do not have. Journal of Financial Economics, 13, 187-221. http://dx.doi.org/10.1016/0304-405X(84)90023-0

Table 1. Development of the Model: Three points on the beta and debt space

\begin{tabular}{|l|l|l|}
\hline & D/A & Beta \\
\hline $\begin{array}{l}\text { Firm at current debt } \\
\text { (Current Point) }\end{array}$ & .1 & .8 \\
\hline $\begin{array}{l}\text { Firm at target debt } \\
\text { (Target Point) }\end{array}$ & .2 & $?$ \\
\hline $\begin{array}{l}\text { Reference firm } \\
\text { (Reference Point) }\end{array}$ & .4 & 1.2 \\
\hline
\end{tabular}


Table 2. Financial data

\begin{tabular}{|c|c|c|c|c|}
\hline & \multicolumn{2}{|c|}{ The Home Depot } & \multicolumn{2}{|c|}{ Lowe's Companies } \\
\hline Ticker & \multicolumn{2}{|l|}{ HD } & \multicolumn{2}{|c|}{ LOW } \\
\hline Exchange & \multicolumn{2}{|c|}{ NYSE } & \multicolumn{2}{|c|}{ NYSE } \\
\hline Fiscal Year End & \multicolumn{2}{|c|}{ 31-Jan } & \multicolumn{2}{|c|}{ 29-Jan } \\
\hline Most Recent Quarter (mrq) & \multicolumn{2}{|c|}{ 31-Oct } & \multicolumn{2}{|c|}{ 29-Oct } \\
\hline Beta (Yahoo! Finance Estimate) & \multicolumn{2}{|c|}{0.81} & \multicolumn{2}{|c|}{1.01} \\
\hline \multicolumn{5}{|l|}{ Balance Sheet (mrq) } \\
\hline Total Assets & $\$$ & 41741000000 & $\$$ & 34341000000 \\
\hline Total Liabilities & $\$$ & 22626000000 & $\$$ & 15449000000 \\
\hline Total Equity & $\$$ & 19115000000 & $\$$ & 18892000000 \\
\hline Stock Price (Close, 29 Oct 2010) & $\$$ & 30.90 & $\$$ & 21.34 \\
\hline Shares Outstanding (mrq) & & 1640000000 & & 1380000000 \\
\hline Market Value of Equity (mrq) & $\$$ & 50676000000 & $\$$ & 29449200000 \\
\hline \multicolumn{5}{|l|}{ Total Firm Value (V) } \\
\hline$(=\mathrm{TL}+\mathrm{MVE})$ & $\$$ & 73302000000 & $\$$ & 44898200000 \\
\hline $\mathrm{D} / \mathrm{V}$ & \multicolumn{2}{|c|}{$30.87 \%$} & \multicolumn{2}{|c|}{$34.41 \%$} \\
\hline
\end{tabular}

Table 3. Estimation of Home Depot's new beta using the Arbitrage Model

$\begin{array}{lcc}\text { New Debt } & \$ & 1500000000 \\ \text { Total Liabilities } & \$ & 24126000000 \\ \text { Total Firm Value } & \$ & 74802000000 \\ \text { D/V } & & 32.25 \%\end{array}$

\begin{tabular}{lrr} 
& $\mathrm{D} / \mathrm{V}$ & Beta \\
\hline Current & $30.87 \%$ & 0.81 \\
Proposed & $32.25 \%$ & $?$ \\
Reference & $34.41 \%$ & 1.01
\end{tabular}

Using Equation 4:

0.8883 


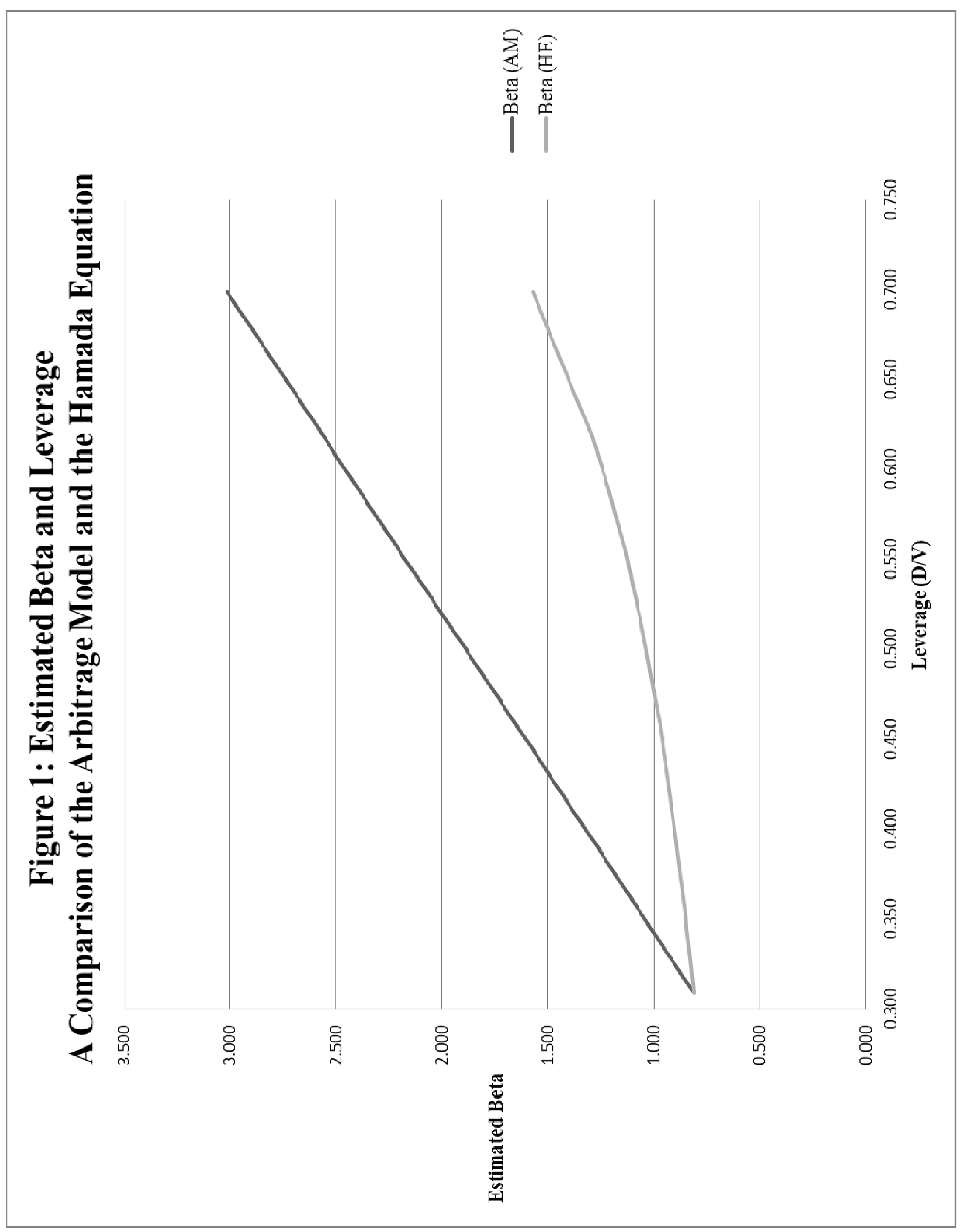

Figure 1. 